\title{
The influence of the fertilizer products, produced from biofuel ash on soil
}

\author{
Kristina BUNEVIČIENĖ - Romas MAŽEIKA \\ Lithuanian Research Centre for Agriculture and Forestry, Institute of Agriculture, Instituto al. 1, Akademija, \\ Lithuania; E-mail: kristina.buneviciene@lammc.lt
}

Keywords: biofuel ash, granulated ash, compost, fertilizer

\section{Introduction}

Biofuel ash is alkaline waste $(\mathrm{pH} \sim 13)$ (Yliniemi, 2016). It is therefore very useful to use it where there are acidic soils $(\mathrm{pH}<5.5)$. In ash contains a lot of nutrients $(\mathrm{K}, \mathrm{P}, \mathrm{Ca}$, $\mathrm{Mg}$ ), which are necessary for plants and soil (Poykio, 2016). Biofuel ash can be practiced by as agriculture fertilizer. The environment benefits when less waste ends up in landfill sites and nutrients are returned to the environment from which they came. Biofuel ash is generally used for fertilization because of its very long-lasting fertilizing effect.

The aim of the research is to evaluate the influence of biofuel ash and fertilizer products (granular ash and ash and compost mixtures) on the changes in soil $\mathrm{pH}$, phosphorus, potassium, calcium, magnesium and heavy metals concentrations in time.

The biofuel ash granules should be hard enough to promote gradual and slow dissolution of nutrients to the forest soil during several years. On the other hand, too high compressive strength may also be problematic since it can retard and possibly prevent the leaching of nutrients (Pesonen, 2016). Composting process result is a new product which has micro and macro elements, organic matter and other nutrients useful for plants and soil.

\section{Materials and methods}

Pot experiment was carried out at the Lithuanian Research Centre for Agriculture and Forestry Agrochemical Research Laboratory's vegetation testing site for two years. The treatments of experiment are: no fertilized, fertilized with biofuel ash (at 3,0 t/ha), compost (20 t/ha), compost and biofuel ash mixes, where compost:biofuel ash $20 \mathrm{t} / \mathrm{ha}: 1,5 \mathrm{t} / \mathrm{ha}, 20$ $\mathrm{t} / \mathrm{ha}: 3,0 \mathrm{t} / \mathrm{ha}$ and $20 \mathrm{t} / \mathrm{ha}: 4,5 \mathrm{t} / \mathrm{ha}$, as well as granulated ash, where ash is $30 \%, 50 \%$ and $70 \%$.

$\mathrm{pH}_{\mathrm{H} 2 \mathrm{O}}$ was measured by a combined (mixed) electrode. Chemical composition (phosphorus, potassium, calcium, magnesium) was analyzed using the atomic-emission spectrometer (AAS) and heavy metals (cadmium, copper, chromium, zinc, lead, nickel) using the plasma optical emission spectrometry (ICP-OES). Granulated ashes structure were performed using X-ray diffraction.

\section{Results and discussion}

The concentrations of heavy metals $(\mathrm{Cd}, \mathrm{Cr}, \mathrm{Cu}, \mathrm{Pb}, \mathrm{Ni}$, and $\mathrm{Zn})$ in the biofuel ash, compost and biofuel ash granules were sufficiently low not to prevent their use in agriculture fertilizer. Overall, the concentrations of nutrients $(\mathrm{Ca}, \mathrm{Mg}, \mathrm{K}$, and $\mathrm{P})$ were reasonably high. 
Table 1: Chemical indicators of different types of fertilizing products

\begin{tabular}{|c|c|c|c|c|c|c|c|c|}
\hline \multirow[t]{3}{*}{ Indicators } & \multicolumn{8}{|c|}{ Fertilizer products } \\
\hline & \multirow{2}{*}{ Biofuel ash } & \multirow[t]{2}{*}{ Compost } & \multicolumn{3}{|c|}{ Biofuel ash and compost mixes } & \multicolumn{3}{|c|}{ Granulated ash } \\
\hline & & & $\begin{array}{c}1,5 \mathrm{t} \\
\text { biofuel ash in } \\
\operatorname{mix}\end{array}$ & $\begin{array}{c}3 \mathrm{t} \\
\text { biofuel ash } \\
\text { in mix }\end{array}$ & $\begin{array}{l}4,5 \mathrm{t} \\
\text { biofuel ash } \\
\text { in mix }\end{array}$ & $\begin{array}{c}30 \% \\
\text { biofuel ash } \\
\text { in granule }\end{array}$ & $\begin{array}{l}50 \% \\
\text { biofuel ash } \\
\text { in granule }\end{array}$ & $\begin{array}{c}70 \% \text { biofuel } \\
\text { ash in } \\
\text { granule }\end{array}$ \\
\hline pH & $12,9 \pm 0,05$ & $9,1 \pm 0,07$ & $9,4 \pm 0,07$ & $9,6 \pm 0,07$ & $9,8 \pm 0,07$ & $12,7 \pm 0,07$ & $12,8 \pm 0,08$ & $12,8 \pm 0,06$ \\
\hline $\mathrm{K}_{2} \mathrm{O} \%$ & $5,70 \pm 0,125$ & $0,39 \pm 0,049$ & $0,76 \pm 0,054$ & $1,08 \pm 0,059$ & $1,37 \pm 0,063$ & $1,29 \pm 0,058$ & $2,13 \pm 0,047$ & $3,51 \pm 0,089$ \\
\hline $\mathrm{P}_{2} \mathrm{O}_{5} \%$ & $3,86 \pm 0,218$ & $0,44 \pm 0,078$ & $0,68 \pm 0,088$ & $0,88 \pm 0,096$ & $1,07 \pm 0,104$ & $0,77 \pm 0,025$ & $1,51 \pm 0,059$ & $2,39 \pm 0,068$ \\
\hline $\mathrm{Ca} \%$ & $30,2 \pm 1,54$ & $3,19 \pm 0,638$ & $5,08 \pm 0,701$ & $6,70 \pm 0,755$ & $8,16 \pm 0,804$ & $34,9 \pm 1,26$ & $33,3 \pm 1,02$ & $26,7 \pm 2,11$ \\
\hline$M g \%$ & $2,43 \pm 0,214$ & $0,46 \pm 0,011$ & $0,60 \pm 0,025$ & $0,72 \pm 0,037$ & $0,83 \pm 0,048$ & $0,92 \pm 0,014$ & $1,44 \pm 0,057$ & $1,41 \pm 0,047$ \\
\hline $\mathrm{Cd} \mathrm{mg/kg}$ & $5,23 \pm 0,351$ & $0,22 \pm 0,007$ & $0,57 \pm 0,031$ & $0,87 \pm 0,052$ & $1,14 \pm 0,070$ & $1,27 \pm 0,027$ & $2,53 \pm 0,049$ & $2,60 \pm 0,037$ \\
\hline $\mathrm{Pb} \mathrm{mg} / \mathrm{kg}$ & $9,07 \pm 0,368$ & $16,8 \pm 2,90$ & $16,3 \pm 2,72$ & $15,8 \pm 2,57$ & $15,4 \pm 2,43$ & $6,93 \pm 0,98$ & $7,57 \pm 0,84$ & $6,77 \pm 0,85$ \\
\hline $\mathrm{Ni} \mathrm{mg} / \mathrm{kg}$ & $8,13 \pm 0,147$ & $6,53 \pm 0,424$ & $6,64 \pm 0,405$ & $6,74 \pm 0,388$ & $6,82 \pm 0,373$ & $7,33 \pm 0,158$ & $7,97 \pm 0,169$ & $8,80 \pm 0,187$ \\
\hline $\mathrm{Cr} \mathrm{mg/kg}$ & $30,3 \pm 1,69$ & $12,1 \pm 0,42$ & $13,4 \pm 0,51$ & $14,5 \pm 0,59$ & $15,4 \pm 0,65$ & $21,7 \pm 3,58$ & $22,3 \pm 3,98$ & $23,1 \pm 4,02$ \\
\hline $\mathrm{Cu} \mathrm{mg} / \mathrm{kg}$ & $123 \pm 10,1$ & $30,8 \pm 1,27$ & $37,3 \pm 1,89$ & $42,8 \pm 2,42$ & $47,8 \pm 2,89$ & $22,6 \pm 1,25$ & $41,2 \pm 2,69$ & $48,8 \pm 2,98$ \\
\hline $\mathrm{Zn} \mathrm{mg/kg}$ & $703 \pm 15,2$ & $168 \pm 9,9$ & $205 \pm 10,3$ & $238 \pm 10,6$ & $266 \pm 10,9$ & $140 \pm 2,9$ & $295 \pm 4,3$ & $317 \pm 6,8$ \\
\hline
\end{tabular}

The pot experiment was found that the $\mathrm{pH}$ value reached the highest value using granulated ash, in which $30 \%$ biofuel ash (3,0 t/ha) ranged from 4,6 to 6,7. The amount of nutrients (potassium, calcium and magnesium) has doubled with compost mixtures (when biofuel ash is 4,5 t/ha). Meanwhile, phosphorus has not changed significantly. Cadmium, copper, zinc and lead incorporated with composts increased the concentration of these elements in the soil. This didn't have an effect on barley growth, the grain yield increased by $30 \%$ compared to control.

\section{Conclusions}

During vegetation, the consumption of minerals was recorded, which confirmed that the growth of spring barley absorbed most of the nutrients from the soil. Meanwhile, the loss of material was reduced to the end of vegetation, and therefore the concentration of minerals increased again. After measuring the concentrations of $\mathrm{Cd}, \mathrm{Cr}, \mathrm{Cu}, \mathrm{Pb}, \mathrm{Ni}$, and $\mathrm{Zn}$, it became clear that the soil was not contaminated with heavy metals, proving that these materials did not damage plant vegetation.

\section{Acknowledgement}

This study is Ph.D work, witch doing in Lithuanian Research Centre for Agriculture and Forestry, Institute of Agriculture, Agrobiology laboratory.

\section{References}

Yliniemi J., Nugteren H., Illikainen M., Tiainen M., Weststrate R., Niinimaki J. (2016): Lightweight aggregates produced by granulation of peat - wood fly ash with alkali activator. International Journal of Mineral Processig. 149. 42-49. https://doi.org/10.1016/j.minpro.2016.02.006

Poykio R., Makela M., Watkins G., Urmesniemi H., Dahl O. (2016): Heavy metals leaching in bottom ash fly ash fractions from industrial - acale BFB - boiler for environmental risks assessment. Transactions of Nonferrous Metals Society of China. 26. 256-264. https://doi.org/10.1016/s1003-6326(16)64112-2

Pesonen J., Kuokkanen V., Kuokkanen T., Illikainen M. (2016): Co-granulation of bio-ash with sewage sludge and lime for fertilizer use. Journal of Environmental Chemical Engineering. 4. 4817-4821. https://doi. org/10.1016/j.jece.2015.12.035 